\title{
Influence of Nb Micro-alloying on TRIP Steels Treated by Continuous Cooling Process
}

Ludmila Kučerová, Hana Jirková, Bohuslav Mašek,

RTI, UWB in Pilsen, Universitni 8, 30614 Pilsen, Czech Republic. E-mail: skal@rti.zcu.cz, h.jirkova@email.cz, masekb@kmm.zcu.cz

TRIP (transformation induced plasticity) steels are low alloyed steels with multiphase microstructure consisting of ferrite, carbide-free bainite and retained austenite. They are typically produced by thermo-mechanical treatment, which involves the hold in bainite transformation region. The hold ensures enough bainite in the final microstructure and also helps to stabilize higher amount of retained austenite. Due to transformation induce plasticity effect; TRIP steels possess very good combination of high strength and high ductility. In response to industrial demands, C-Mn-Si and C-Mn-Si-Nb TRIP steels were subjected to thermo-mechanical treatment with continuous cooling which corresponded to real rolling mill processing of the steel with similar chemical compositions. Typical TRIP microstructures with 10-15\% of retained austenite were achieved for both steels after optimization of cooling schedules. However, cooling by two different cooling rates had to be applied to $\mathrm{C}$-Mn-Si steel to obtain the convenient microstructure. Beneficial effect of $\mathrm{Nb}$ micro-alloying on low sensitivity of TRIP steel to variations in cooling parameters has been found out. Mechanical properties of the most convenient microstructures were very promising, ultimate tensile strength reached $850 \mathrm{MPa}$ with ductility $\mathrm{A}_{5 \mathrm{~mm}}$ around $25 \%$.

Keywords: TRIP steel, continuous cooling, retained austenite

\section{Acknowledgement}

The present contribution has been prepared under project LO1502 'Development of the Regional Technological Institute' under the auspices of the National Sustainability Programme I of the Ministry of Education of the Czech Republic aimed to support research, experimental development and innovation.

\section{Reference}

[1] ZAEFFERERA, S., OHLERTB, J., BLECK, W. (2004). A study of microstructure, transformation mechanisms and correlation between microstructure and mechanical properties of a low alloyed TRIP steel. In: Acta Materialia, Vol. 52 , pp. 2765-2778.

[2] B.C. De COOMAN (2004). In: Current Opinion in Solid State and Materials Science, Vol. 8, pp. $285-303$.

[3] SHEN, Y.F., QIU, L.N., SUN, X.,et.al. (2015). Effects of retained austenite volume fraction, morphology, and carbon content on strength and ductility of nanostructured TRIP-assisted steels. In: Materials Science and Engineering: A, Vol. 636, pp. 551-564.

[4] LI, L. , B.C.De COOMAN, WOLlANTS, P., HE, Y., ZHOU, X. (2004). Effect of Aluminum and Silicon on Transformation Induced Plasticity of the TRIP Steel. In: J. Mater. Sci. Technol., Vol. 20, pp. 135-138.

[5] CHIANG, J., BOYD, J.D., PILKEY, A.K. (2015). Effect of microstructure on retained austenite stability and tensile behaviour in an aluminum-alloyed TRIP steel. In: Materials Science and Engineering: A, Vol. 638, pp. 132-142.

[6] HULKA, K. (2005). The Role of Niobium in Cold Rolled TRIP Steel. In: Materials Science Forum, Vols. 473474, pp. 91- 102.

[7] FENG, Q., LI, L., YANG, W., SUN, Z. (2014). Microstructures and mechanical properties of hot-rolled Nb-microalloyed TRIP steels by different thermo-mechanicalprocesses. In: Materials Science and Engineering: A, Vol. 605, pp. 14-21.

[8] MASEK, B., JIRKOVA, H., KUCEROVA, L., et al. (2011). Material-Technological Modelling of Various Holding Times at Partitioning Temperature in AHSS with Different Alloying Strategies, In: Advances in Heterogeneous Material Mechanics 2011, pp. 701-704.

[9] GREJCAR, A., SKRZYPCZYK P., WOZNIAK, D. (2014). Thermomechanically Rolled Medium-Mn Steels Containing Retained Austenite. In: Archives of Metallurgy and Materials, Vol. 59, No. 4, pp. 1691-1697.

[10]KUČEROVÁ, L., JIRKOVÁ, H., MAŠEK, B. (2015). Continuous cooling of CMnSi TRIP steel. In: Materials Today: Proceedings, Vol. 2, Sup. 3, pp. S677-S680, International Conference on Martensitic Transformations, ICOMAT-2014.

[11]LI, Z., DI, W, LV ,H., FANG S. (2007). Continuous Cooling Transformation Behaviour of C-Si-Mn TRIP Steel. In: Journal of Iron and Steel Research, International, Vol. 14, No. 5, pp. 277-281. 
[12]MASEK, B., STANKOVA, H., MALINA, J. et al. (2007). Physical Modelling of Microstructure Development during Technological Processes with Intensive Incremental Deformation. In: Mechanical Behavior of Materials $X$, Vols. 345-346, pp. 943-946.

[13]MAŠEK, B., JIRKOVÁ, H., KUČEROVÁ, L., et al. (2011). Material-technological Modelling of Real Thin Sheet Rolling Process. In: Proceedings of METAL 2011, pp.2016-220, TANGER, Ostrava.

[14]MAŠEK, B., STAŇKOVÁ, H., NOVÝ, Z.; et al. (2009). The Influence of Thermomechanical Treatment of TRIP Steel on its Final Microstructure. In: Journal of Materials Engineering and Performance, Vol. 18, No. 4, pp. 385389.

Copyright (C 2016. Published by Manufacturing Technology. All rights reserved. 